\title{
EKSTRAKSI DAN KARAKTERISASI PEKTIN DARI KULIT BUAH KLUWIH (Artocarpus camansi Blanco)
}

\section{[Extraction and Characterization of Pectin from Artocarpus Camansi Fruit Peels (Artocarpus camansi Blanco)]}

\author{
Yesy Febriyanti ${ }^{{ }^{*}}$, Abd. Rahman Razak ${ }^{1}$, Ni Ketut Sumarni ${ }^{1}$ \\ 1 Jurusan Kimia Fakultas MIPA, Universitas Tadulako \\ J. Soekarno Hatta Km.9, Kampus Bumi Tadulako Tondo Palu, Telp. 0451- 422611 \\ *)Coresponding author: yesyfebriyanti2@gmail.com
}

Diterima 11 Januari 2018, Disetujui 26 Februari 2018

\begin{abstract}
Research about extraction and characterization of pectin from fruit peel of artocarpus camansi (Artocarpus camansi Blanco) has been done. The objective of this research is to determine the ratio and the best time necessary to produce a pectin extract with the highest yield. Statistically, this study used a completely randomized design (CRD), which consisted of 2 factors, the ratio of the sample to the solvent and extraction time, whereas those factors were done triplicate. The results showed that the best ratio was $1: 50 \mathrm{~b} / \mathrm{v}$ with $47.2 \%$ yield of pectin. Based of the time extraction, the best rendemen was obtained at 120 minutes with $48.30 \%$ yield of pectin. The result of pectin characterization indicated that the water content of $1.55 \%$, ash content of $2.2 \%$, equivalent weight of $609.99 \mathrm{mg}$, methoxyl of $11.49 \%$, galakturonat levels of $42.47 \%$, the degree of esterification of $47.65 \%$ and a molecular weight of $16177.83 \mathrm{~g} / \mathrm{mol}$.
\end{abstract}

Keywords: extraction, characterization, pectin, Artocarpus camansi.

\begin{abstract}
ABSTRAK
Telah dilakukan penelitian tentang ekstraksi dan karakterisasi pektin dari kulit buah kluwih (Artocarpus camansi Blanco). Penelitian ini bertujuan untuk mengetahui rasio dan waktu terbaik yang diperlukan untuk menghasilkan ekstrak pektin dengan rendemen tertinggi. Penelitian ini menggunakan Rancangan Acak Lengkap (RAL) yang terdiri atas 2 faktor yaitu rasio perbandingan sampel terhadap pelarut dan waktu ekstraksi yang masing-masing dilakukan sebanyak 3 kali. Hasil penelitian menunjukan bahwa rasio terbaik diperoleh pada perbandingan 1:50 b/v dengan rendemen pektin 47,2\% dan waktu terbaik diperoleh pada 120 menit dengan rendemen 48,30\%. Hasil karakterisasi pektin yang diperoleh antara lain yaitu kadar air 1,55\%, kadar abu 2,2 \%, berat ekivalen $609,99 \mathrm{mg}$, metoksil $11,49 \%$, kadar galakturonat $42,47 \%$, derajat esterifikasi $47,65 \%$ dan berat molekul $16.177,83 \mathrm{~g} / \mathrm{mol}$.
\end{abstract}

Kata Kunci : ekstraksi, karakterisasi, pektin, kluwih. 


\section{LATAR BELAKANG}

Pektin merupakan jenis biopolymer golongan karbohidrat yang terdiri dari asam $\alpha$-D-galakturonat yang mengandung metil ester dan dapat diekstraksi dari kulit buah menggunakan pelarut asam. Senyawa ini banyak dimanfaatkan sebagai bahan stabilizer pada produk pangan, bahan pembuatan jelly dan pembentuk film (Willat et al., 2006).

Pektin bisa didapatkan dari semua tanaman yang berfotosintesis yang terletak dalam persimpangan zona antara sel-sel dengan dinding sekunder termasuk xilem dan sel-sel serat dalam jaringan kayu. Menurut O'Neil MA et al. (2014) pektin pada tanaman juga banyak terdapat pada lapisan kulit pada buah, seperti pektin dari kulit buah nagka (Injilaudin dan Nugroho, 2015), kulit buah pepaya (Nurviani et al., 2014), limbah kulit pisang (Tuhuloula et al., 2013) dan kulit buah coklat (Susilowati et al., 2013) telah banyak dijadikan sebagai sumber pektin. Jenis bahan pangan lain sebagai sumber pektin terus dikaji. Mengingat kebutuhan pektin dibidang industri dan farmasi konsumsi pektin dunia dari tahun ke tahun semakin meningkat (Budiyanto dan Yulianingsih, 2008). Hal ini menjadi alasan bagi para ilmuan untuk menemukan sumber pektin yang lain, salah satunya adalah kulit buah kluwih.

Kluwih (Artocarpus camansi Blanco) merupakan merupakan salah satu tanaman yang dapat hidup di daerah beriklim tropis, seperti di Sulawesi Tengah khususnya di desa Oloboju kabupaten Sigi masih banyak terdapat tanaman kluwih tumbuh dengan subur dan memiliki kemampuan hidup tinggi walaupun berada di habitat yang kurang menguntungkan. Buah kluwih oleh penduduk desa Oloboju biasa diolah sebagai bahan pembuat sayur, sehingga konsumsi buah kluwih menghasilkan limbah berupa kulit buah kluwih yang belum dimanfaatkan secara optimal. Oleh karena itu, untuk meningkatkan nilai tambahnya, limbah kulit buah kluwih tersebut dapat dimanfaatkan sebagai sumber pektin.

Pemisahan pektin dari jaringan tanaman umumnya menggunakan ekstraksi dengan pelarut yang bersifat asam (Nurhikmat, 2003). Beberapa penelitian ekstraksi pektin telah dilakukan, seperti ekstraksi pektin dari kulit buah pepaya (Nurviani et al., 2014) dan kulit buah nagka (Injilaudin et al., 2015). Prasetyowati et al.. (2009) mengemukakan bahwa terdapat beberapa faktor yang mempengaruhi ekstraksi pektin, antara lain waktu kontak, jenis pelarut, suhu ekstraksi, rasio antara sampel, dan pelarut serta jenis pelarut yang digunakan.

Rasio pelarut terhadap sampel yang diekstraksi sangat berpengaruh terhadap jumlah pektin yang dihasilkan karena pada jumlah tertentu pelarut memiliki keterbatasan untuk berikatan dengan molekul-molekul pektin. Menurut Christiani et al. (2014) rasio antara ampas apel manalagi terhadap pelarut asam sitrat $5 \%$ adalah 1:105 (b/v) dengan rendemen 
10,59 \%. Menurut Putra (2010), rasio terbaik antara dami buah nangka terhadap pelarut $\mathrm{HCl}$ adalah 1:5 (b/v) dengan rendemen $4,54 \%$.

Produk pektin juga sangat dipengaruhi oleh waktu ekstraksi. Injilaudin dan Nugroho (2015) melaporkan bahwa waktu ekstraksi terbaik kulit buah nangka dalam pelarut $\mathrm{HCl}$ yaitu 90 menit dengan rendemen 4,68 \%. Nurviani et al. (2014) menyatakan bahwa waktu ekstraksi terbaik kulit buah pepaya semangka dalam pelarut asam sitrat $5 \%$ yaitu selama 120 menit dengan rendemen pektin $12,70 \%$.

Asam mineral ataupun asam organik, seperti asam sulfat, asam klorida, asam nitrat, asam asetat, dan asam sitrat adalah jenis pelarut yang digunakan pada ekstraksi pektin (Fitriani, 2003). Pelarut asam berperan dalam memisahkan ion polivalen, memutus ikatan antara asam pektinat dengan selulosa, menghidrolisis protopektin, dan menghidrolisis gugus metil ester (Kertesz, 1951). Menurut Arviani (2009) asam sitrat merupakan pelarut yang baik dari segi ekonomi dan juga dari sudut pandang lingkungan. Berdasarkan uraian tersebut perlu divariasikan waktu dan rasio kulit buah kluwih terhadap pelarut asam sitrat yang digunakan.

\section{METODE PENELITIAN}

\section{Bahan dan Peralatan}

Bahan utama yang digunakan dalam penelitian ini adalah kulit buah kluwih (Artocarpus camansi Blanco) matang yang diperoleh dari Desa Oloboju Kecamatan Sigi. Bahan kimia yang digunakan untuk ekstraksi pektin antara lain asam sitrat $5 \%$, akuades, natrium hidroksida $\mathrm{NaOH}, \mathrm{KBr}$, indikator phenolftalein, kertas saring, indikator universal, aluminium foil dan etanol $96 \%$.

Adapun Peralatan yang digunakan selama penelitian ini antara lain pisau, ayakan 60 mesh (elektrolab, india), batang pengaduk, neraca analitik (adam, england), hot plate (wisestir, germany), viscosimeter (Ostwald, agra dyalbagh), magnet stirer, blender, tanur (nabertherm, germany), spektrofotometer FTIR (prestige 21 shimadzu, japan), oven analitik (EYELA NDO - 400, tokyo), corong buchner, cawan petri, statif dan klem, stopwatch, dan alatalat gelas yang umum digunakan dalam laboratorium.

\section{Prosedur Penelitian}

\section{Preparasi sampel}

Kulit buah kluwih dipisahkan dari daging dan bijinya, kemudian dicuci dengan air mengalir hingga bersih. Setelah itu, kulit dikeringkan dengan menggunakan sinar matahari. Selanjutnya kulit buah yang kering diblender dan diayak dengan ayakan 60 mesh hingga diperoleh tepung.

\section{Penentuan rasio tepung kulit buah kluwih terhadap pelarut asam sitrat (Nurviani et al., 2014)}

Sampel ditimbang sebanyak 10 gram, kemudian ditambahkan pelarut sesuai dengan variasi perbandingan bahan dan pelarut, yaitu 1:30, 1:40, 1:50, 
1:60 dan $1: 70 \mathrm{~b} / \mathrm{v}$, dengan pelarut asam sitrat $5 \%$. Kemudian di ekstraksi diatas penangas dengan waktu ekstraksi 120 menit dan suhu $90-95{ }^{\circ} \mathrm{C}$ dengan kecepatan pengadukan $600 \mathrm{rpm}$. Setelah diekstrasi, kemudian ekstrak disaring menggunakan corong buchner guna memisahkan ampas dan filtratnya. Filtrat yang di peroleh diuapkan pada suhu 100 ${ }^{0} \mathrm{C}$ sampai volume mencapai setengahnya, selanjutnya didinginkan.

\section{Penentuan waktu kontak tepung kulit buah kluwih dengan pelarut asam sitrat (Susilowati et al., 2013)}

Sampel ditimbang sebanyak 10 gram, kemudian ditambahkan pelarut sesuai dengan variasi perbandingan bahan dan pelarut terbaik yaitu 1:50 b/v. Rasio terbaik yang diperoleh dipanaskan diatas penangas dengan suhu $90-95{ }^{\circ} \mathrm{C}$ selama 60 menit, 90 menit, 120 menit, 150 menit dan 180 menit, dengan kecepatan pengadukan $600 \mathrm{rpm}$. Setelah diekstrasi, kemudian ekstrak disaring menggunakan corong buchner guna memisahkan residu dan filtratnya. Filtrat yang di peroleh diuapkan pada suhu $100{ }^{\circ} \mathrm{C}$ sampai volume mencapai setengahnya, selanjutnya didinginkan.

\section{Pengendapan pektin (Akhmaludin dan Kurniawan, 2009).}

Pengendapan pektin dilakukan dengan menambahkan etanol $96 \%$ dalam filtrat dengan perbandingan ekstrak pektin/etanol $96 \% 1: 1 \quad(\mathrm{v} / \mathrm{v})$. filtrat pektin tersebut didiamkan selama 24 jam. Endapan pektin yang terbentuk dipisahkan dari larutannya menggunakan corong buchner.

Pencucian pektin (Akhmaludin dan Kurniawan, 2009).

Tambahkan etanol $96 \%$ pada pektin yang telah diperoleh sambil diaduk dan dibiarkan sampai mengendap untuk kemudiam disaring dengan menggunakan kertas saring. Hal ini dilakukan beberapa kali sampai etanol bekas pencucian berwarna jernih dan tidak bereaksi dengan asam, adapun tanda dari tidak lagi bereaksi dengan asam adalah ketika air bekas pencucian berwarna merah muda bila ditetesi dengan indikator PP.

Pengeringan pektin (Hanum et al., 2012).

Pektin basah hasil pengendapan dikeringkan dalam oven pada suhu $40^{\circ} \mathrm{C}$ selama 24 jam. Hasil yang diperoleh disebut pektin kering yang selanjutnya dikarakterisasi, meliputi penentuan kadar air, abu, metoksil, galaktronat, berat ekivalen, berat molekul, dan spektrum IR.

Penentuan kadar air (Pardede et al., 2013).

Sebanyak 0,3 gram sampel pektin di keringkan didalam oven pada suhu $105^{\circ} \mathrm{C}$ selama 4 jam menggunakan cawan porselin yang telah diketahui bobot kosongnya. Selanjutnya di dinginkan dalam desikator dan ditimbang sampai diperoleh bobot yang tetap.

Penentuan kadar abu (Ranganna, 2000).

Cawan porselin dikeringkan didalam tanur pada suhu $650{ }^{\circ} \mathrm{C}$ kemudian didinginkan didalam desikator dan 
ditimbang sebagai bobot wadah. Sebanyak 0,5 gram sampel pektin dimasukkan dalam cawan porselin yang telah diketahui bobotnya kemudian dimasukkan dalam tanur dengan suhu 650 ${ }^{\circ} \mathrm{C}$ selama 4 jam. Kemudian didinginkan dalam desikator dan ditimbang sampai diperoleh bobot tetap.

\section{Penentuan berat ekivalen (Ranganna, 2000).}

Berat ekivalen ditentukan dengan menimbang 0,25 gram pektin dimasukkan dalam Erlenmeyer $250 \mathrm{ml}$ dan dilembabkan dengan 1,0 ml etanol $96 \%$. Kemudian ditambahkan dengan akuades sebanyak $50 \mathrm{ml}$ dan ditambahkan 6 tetes indikator PP (phenolphthalein). Campuran tersebut kemudian diaduk dengan cepat untuk memastikan bahwa semua substansi pektin telah terlarut dan tidak ada gumpalan yang menempel pada sisi Erlenmeyer. Titrasi dilakukan perlahanlahan dengan titran standar $\mathrm{NaOH} 0,1 \mathrm{~N}$ sampai warna campuran berubah menjadi merah muda dan tetap bertahan selama 30 detik.

$\begin{aligned} & \text { Penentuan kadar } \\ & \text { (Akhmalludin, 2009). } \\ & \text { Pektin kering yang diperoleh }\end{aligned}$
dianalisis kandungan metoksilnya.
Dilakukan dengan cara melarutkan $0,25 \mathrm{gr}$
pektin kering dengan $50 \mathrm{ml}$ akuades.
Setelah itu ditambahkan dengan 6 tetes
fenolftalin, kemudian dititrasi dengan
NaOH $0,1 \mathrm{~N}$. Titik ekivalen ditandai
dengan perubahan warna dari putih
kecoklatan sampai kemerah muda.
Volume $\mathrm{NaOH}$ yang dibutuhkan dicatat.

Selanjutnya ditambahkan 6 tetes larutan HCL 0,1 $\mathrm{N}$ dan dikocok, kemudian larutan didiamkan selama 15 menit.

Kadar galakturonat (Akhmalludin, 2009)

Larutan hasil pendiaman pada penentuan kadar metoksil kemudian dikocok sampai warna merah muda hilang dan ditambahkan 6 tetes fenoftalin serta dititrasi dengan $\mathrm{NaOH} \quad 0,1 \mathrm{~N}$ sampai timbul warna merah muda. Derajat Esterifikasi (DE) dari pektin dapat diperoleh dari perbandingan kadar metoksil dan galakturonat.

\section{Penentuan Berat Molekul (Ngadiwiyana, 1996)}

Pektin dilarutkan dalam aquades hingga konsentrasinya 0,02 $\mathrm{g} / \mathrm{mL}$. kemudian dibuat variasi konsentrasi melalui pengenceran dengan aquades : $0,01500 \mathrm{~g} / \mathrm{mL} ; 0,01000 \mathrm{~g} / \mathrm{mL} ; 0,00500$ $\mathrm{g} / \mathrm{mL} ; 0,00250 \mathrm{~g} / \mathrm{mL}$; dan 0,00125 g/mL. Dilakukan pengukuran waktu alir pelarut yaitu aquades dan masing-masing konsentrasi larutan dengan menggunakan viskometer ostwald, sehingga diperoleh $\mathrm{t}_{0}$, $t_{1}, t_{2}, t_{3}, t_{4}, t_{5}$ dan $t_{6}$. Berat molekul dihitung dengan persamaan Mark-Houwink:

Viskositas relatif $\quad \eta r=\eta / \eta 0 \cong t / t o$

Viskositas spesifik $\eta s p=\eta r-1$

Viskositas intrinsik $[\eta]=(\eta s p / c)$

$$
\eta=[K M]^{\alpha}
$$




\section{HASIL DAN PEMBAHASAN}

\section{Rendemen pektin pada rasio perbandingan bahan dan pelarut asam sitrat $5 \%$}

Berdasarkan hasil yang diperoleh yang ditunjukan pada (Gambar 1), bahwa rendemen pektin tertinggi diperoleh pada rasio $1: 50 \mathrm{~b} / \mathrm{v}$ yaitu $47,2 \%$ dan pada rasio $1: 60 \mathrm{~b} / \mathrm{v}$ rendemen menurun. Banyaknya pelarut yang berinteraksi dengan sampel akan menyebabkan pektin terlepas dari jaringan dinding sel akibatnya pektin akan berubah menjadi asam pektat sehingga menurunkan kadar pektin (Prasetyowati dan Pesantri, 2009). Pektin cenderung tidak stabil pada saat ion $\mathrm{H}^{+}$berlebih karena terjadi pemutusan ikatan glikosidik molekul poligalakturonat sehingga hasil hidrolisis molekul protopektin lebih sedikit. Prasetyowati dan Pesantri (2009) juga menyatakan jumlah pelarut harus cukup untuk melarutkan zat terlarut sampai tingkat yang diinginkan. Ekstraksi padatcair akan semakin cepat apabila volume pelarut semakin tinggi.

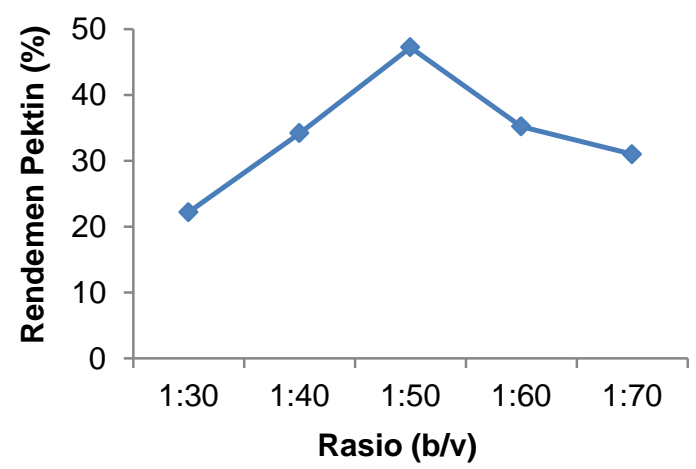

Gambar 1 Pengaruh rasio bahan dan pelarut terhadap rendemen pektin

Berdasarkan hasil analisis sidik ragam menggunakan SPSS dengan taraf kepercayaan 95\% $(\alpha=0,05)$ dengan nilai sign ( $p$ value) $<\alpha$ yang menunjukkan bawah rasio tepung kulit buah kluwih (b/v) berpengaruh nyata terhadap rendemen pektin yang dihasilkan, oleh karena itu dapat dilakukan analisis lanjut dengan uji Duncan untuk menentukan rasio terbaik tepung kulit buah kluwih.

Hasil uji lanjut Duncan dengan taraf kepercayaan 95\% $(\alpha=0,05)$ menunjukkan rasio tepung kulit buah kluwih (b/v) berada pada kolom subset yang berbeda. Dari hasil uji Duncan menunjukkan terbentuknya 5 kolom subset dimana rasio 1 : $30 \mathrm{~b} / \mathrm{v}$ terisi pada kolom subset pertama, rasio $1: 70 \mathrm{~b} / \mathrm{v}$ terisi pada kolom subset kedua, rasio $1: 40 \mathrm{~b} / \mathrm{v}$ terisi pada kolom subset ketiga, rasio $1: 60 \mathrm{~b} / \mathrm{v}$ terisi pada kolom subset keempat, dan rasio $1: 50 \mathrm{~b} / \mathrm{v}$ terisi pada kolom subset kelima. Berdasarkan data tersebut, dapat disimpulkan bahwa rasio $1: 30,1: 70,1: 40$, 1:60 dan $1: 50 \mathrm{~b} / \mathrm{v}$ berbeda nyata. Dengan demikian, rasio $1: 50 \mathrm{~b} / \mathrm{v}$ yang memiliki rendemen tertinggi dapat direkomendasikan untuk diaplikasikan dalam ekstraksi pektin dari kulit buah kluwih.

Rendemen pektin rasio $1: 50 \mathrm{~b} / \mathrm{v}$ dari hasil penelitian ini lebih tinggi dibandingkan dengan rendemen pektin Christiani et al. (2014) pada ampas apel manalagi adalah 18,57 \%, Nurviani et al. (2014) pada kulit buah pepaya varietas semangka adalah $12,70 \%$ dan Putra I (2010) pada dami buah nangka dari hasil penelitian yang ada antara lain 4,54 \%. 
Perbedaan rendemen pektin yang diperoleh disebabkan oleh perbedaan sampel, pelarut asam dan konsentrasi asam yang digunakan.

\section{Rendemen pektin pada berbagai waktu ekstraksi}

Ekstraksi pektin tidak hanya dipengaruhi oleh rasio, tetapi juga dipengaruhi oleh waktu ekstraksi (Prasetyowati et al., 2009). Adapun rasio yang diterapkan adalah 1:50 (b/v) yang merupakan rasio ektraksi terbaik pada perlakuan sebelumnya. Penelitian ini menerapkan variasi waktu ekstraksi 60 menit, 90 menit, 120 menit, 150 menit dan 180 menit untuk mendapatkan rendemen pektin. Hasil rendemen pektin yang diperoleh pada (Gambar 2) yaitu 35,80\%, $40,90 \%, 48,30 \%, 46 \%$ dan 41,66 \%. Pada hasil yang diperoleh terlihat bahwa semakin lama waktu ekstraksi, berat pektin yang dihasilkan semakin besar, namun pada waktu ekstraksi 150 menit, berat pektin yang dihasilkan menurun. Menurut Prasetyowati dan Pesantri (2009) hal ini disebabkan ion hidrogen yang mensubstitusi kalsium dan magnesium dari protopektin yang terhidrolisis akan menyebabkan rusaknya molekul pada ikatan rantai galakturonat menjadi terlepas. Menurut Evi et al. (2013) waktu ekstraksi pectin berbanding lurus dengan jumlah protopektin yang berubah menjadi pektin, tetapi pada waktu tertentu pectin dapat terdegradasi menjadi asam pektat, sehingga waktu optimum penting untuk ditentukan.

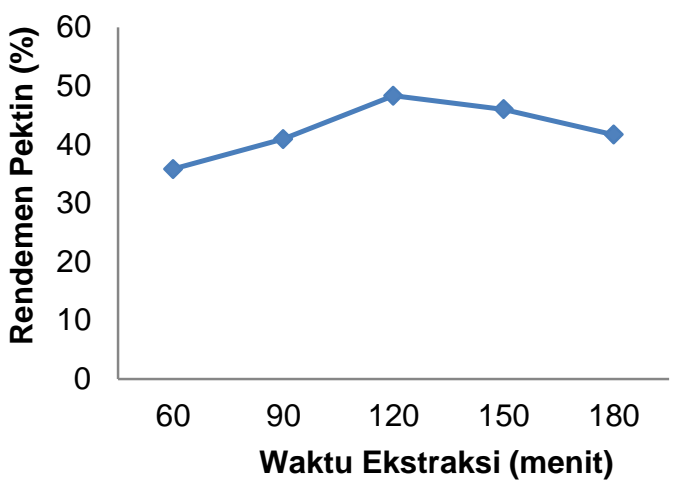

Gambar 2 Rendemen pektin terhadap pengaruh waktu ekstraksi

Hasil analisis sidik ragam menggunakan SPSS dengan taraf kepercayaan $95 \%(\alpha=0,05)$ dengan nilai signifikan ( $p$ value) $<\alpha$ yang menunjukkan bahwa waktu ekstraksi berpengaruh nyata terhadap rendemen pektin yang dihasilkan. Oleh karena itu untuk menentukan waktu ekstraksi terbaik dapat dilakukan analisis lanjut dengan uji Duncan.

Berdasarkan hasil uji lanjut Duncan dengan taraf kepercayaan $95 \%(\alpha=0,05)$, perbedaan tiap kelompok dapat dilihat dari nilai harmonic mean yang dihasilkan tiap kelompok berada dalam kolom subset yang sama atau berbeda. Uji menunjukkan waktu pengocokan berada pada kolom subset yang berbeda. Dari hasil uji Duncan menunjukkan terbentuknya 5 kolom subset dimana waktu 60 menit terisi pada kolom subset pertama, waktu 90 menit terisi pada kolom subset kedua, waktu 180 menit terisi pada kolom subset ketiga, waktu 150 menit terisi pada kolom subset keempat dan waktu 120 menit terisi pada kolom subset kelima. Berdasarkan data tersebut, dapat disimpulkan bahwa 
waktu ekstraksi dari masing - masing subset berbeda nyata terhadap waktu ekstraksi. Dengan demikian waktu ekstraksi 120 menit dapat direkomendasikan untuk diaplikasikan dalam ekstraksi pektin dari tepung kulit buah kluwih.

\section{Karakteristik Pektin}

\section{a. Kadar Air}

Pektin dengan kadar air tinggi akan lebih mudah rusak karena dapat menjadi media tepat bagi mikroorganisme. Berdasarkan hasil pengukuran kadar air pada penelitian diperoleh kadar air pektin kulit buah kluwih adalah 1,55 \%. Menurut IPPA (International Pectin ProducersAssociation) (2003) Syarat kadar air maksimum untuk pektin kering adalah tidak lebih dari $12 \%$, dengan demikian kadar air pektin hasil penelitian ini masih dibawah syarat maksimum yang telah ditetapkan.

Menurut Utami (2014), tingginya kadar air pektin yang dihasilkan dapat dipengaruhi oleh derajat pengeringan pektin yang tidak maksimal sehingga air yang dikandung bahan tidak teruapkan secara sempurna. Penyimpanan pada tempat yang lembab dan wadah yang tidak kedap udara juga akan menyebabkan kerentanan pektin terpapar oleh udara luar, sehingga pektin menjadi lembab kembali (Fitriani, 2003).

\section{b. Kadar abu}

Tingkat kemurnian pektin juga tidak lepas dari kandungan mineralnya yang dapat diketahui dari kadar abu yang terkandung di dalamnya (Budiyanto dan Yulianingsih, 2008). Berdasarkan hasil analisis kadar abu pada pektin kulit buah kluwih, didapatkan kadar abu sebesar 2,2\%. Menurut IPPA (International Pectin Producers Association) (2003) batas maksimum kadar abu pektin adalah tidak lebih dari $10 \%$ dengan demikian kadar abu hasil penelitian ini masih dibawah syarat maksimum yang telah ditetapkan.

Hanum et al. (2012) menyatakan bahwa protopektin dalam buah - buahan dan sayuran berada dalam bentuk kalsium-magnesium pektat dan jika dicampurkan dengan asam akan mengakibatkan terhidrolisisnya pektin dari ikatan kalsium dan magnesiumnya. Komponen $\mathrm{Ca}^{2+}$ dan $\mathrm{Mg}^{2+}$ akan banyak terlarut dalam larutan ekstrak dan ikut mengendap jika reaksi hidrolisis protopektin ditingkatkan, sehingga kadar abu pektin tentu akan tinggi juga.

\section{c. Berat ekivalen}

Berat ekivalen pektin merupakan jumlah asam galakturonat bebas yang tidak teresterifikasi. Asam poligalakturonat yang tidak mengalami esterifikasi disebut juga dengan asam pektat.

Berdasarkan hasil analisis berat ekivalen pada pektin kulit buah kluwih, didapatkan berat ekivalen sebesar 609,99 mg. Berat ekivalen menurut standar IPPA (International Pectin Producers Association) (2003) yakni 600-800 mg. Hasil penelitian ini masih berada pada syarat standar yang telah ditetapkan. Hal 
ini dipengaruhi oleh bobot molekul pektin tergantung pada jenis tanaman, kualitas bahan baku, metode ekstraksi dan perlakuan pada proses ekstraksi. Kemungkinan hal yang mempengaruhi nilai berat ekivalen adalah sifat pektin hasilekstraksi itu sendiri, serta proses titrasi yang dilakukan (Fitria, 2013).

\section{d. Kadar metoksil}

Kadar metoksil didefinisikan sebagai gugus metil teresterifikasi pada ekstraksi kulit buah kluwih. Kadar metoksil berpengaruh terhadap kemampuan pembentukan gel yang baik. Menurut Goycoolea dan Adriana (2003) pektin disebut bermetoksil tinggi jika kadar metoksil sama dengan atau lebih dari $7 \%$, dan disebut bermetoksil rendah jika kadar metoksil kurang dari $7 \%$.

Berdasarkan hasil analisis kadar metoksil pada pektin kulit buah kluwih, didapatkan kadar metoksil sebesar $11,49 \%$. Berdasarkan kadar metoksil tersebut maka pektin yang dihasilkan dalam penelitian ini tergolong dalam pektin metoksil tinggi. Semakin tinggi kadar metoksil dalam molekulnya, maka makin cepat pektin menjadi gel (Hariyanti, 2006).

Pektin dengan kadar metoksil tinggi umumnya dimanfaatkan pada produkparoduk makanan, seperti pudding, selai, dan jeli, sedangkan pectin metoksil rendah sangat sesuai untuk bahan penyalut (coating agent) produk pangan (Silvana, 2013).

\section{e. Kadar asam galakturonat}

Sifat fungsional pectin sangat dipengaruhi oleh kadar asam galakturonat. Struktur dan tekstur dari gel pektin tergantun pada kadar asam galakturonat (Constenla dan Lozano, 2002). Semakin tinggi nilai kadar galakturonat maka mutu pektin juga semakin tinggi. Menurut IPPA (2002) kadar galakturonat yang ditetapkan minimal $35 \%$.

Berdasarkan hasil analisis kadar asam galakturonat pada pektin kulit buah kluwih, didapatkan kadar asam galakturonat sebesar 42,47\%. Berdasarkan kadar asam galakturonat tersebut maka pektin yang dihasilkan dalam penelitian ini telah memenuhi nilai standar yang telah ditetapkan, disebabkan karena reaksi hidrolisis protopektin menjadi pektin yang komponen dasarnya asam D-galakturonat. Menurut Fitriani (2003) menyatakan bahwa selain asam galakturonat, pektin juga mengandung senyawa-senyawa lain yaitu gula netral seperti D-galaktosa, L-arabinosa dan Lramnosa. Senyawa-senyawa non uronat tersebut dapat terbawa pada waktu proses penggumpalan pektin. Senyawa-senyawa inilah yang mempengaruhi komposisi senyawa pektin. Perbedaan komposisi senyawa pektin mempengaruhi juga terhadap kadar galakturonat dipengaruhi oleh metode ekstraksi yang digunakan. Beberapa senyawa non uronat mungkin dapat dihilangkan melalui pelarutan kembali pektin dalam air dan penggumpalan, tetapi tidak mungkin 
menghilangkan semua senyawa non uronat.

\section{f. Derajat esterifikasi}

Darajat esterifikasi merupakan persentase gugus karboksil yang teresterifikasi. Pektin berderajat esterifikasi $>50 \%$ tergolong bermetoksil tinggi, sedangkan < 50\% bermetoksil rendah (Siamornsak, 2003).

Berdasarkan hasil analisis Derajat Esterifikasi pada pektin kulit buah kluwih, didapatkan Derajat Esterifikasi sebesar $47,65 \%$. Menurut standar mutu pektin IPPA (2003), pektin yang dihasilkan dalam penelitian ini termasuk pektin berester rendah karena memiliki derajat esterifikasi kurang dari 50\%, sehingga dapat dikelompokkan kedalam pektin bermetoksil rendah.

Ikatan glikosidik dari rantai senyawa pektin dalam pelarut asam akan cenderung terhidrolisis menghasilkan asam galakturonat. Penggunaan asam dengan konsentrasi tinggi akan menyebabkan perubahan pektin menjadi asam pektat, dimana asam galakturonatnya terbebas dari gugus metil ester (Budiyanto dan Yulianingsih, 2008).

\section{g. Berat molekul pektin}

Berat molekul merupakan variabel yang penting sebab berhubungan langsung dengan sifat kimia polimer. Umumnya polimer dengan berat molekul tinggi mempunyai sifat yang lebih kuat. Banyak sekali bahan polimer yang tergantung pada massa molekulnya (Cowd, 1991). Menurut Sufy (2015) pektin merupakan molekul dengan bobot molekul tinggi $(30.000-100.000 \mathrm{~g} / \mathrm{mol})$ yang terdiri dari unit rantai asam galakturonat terikat dengan ikatan 1,4-a glukosida.

Penentuan berat molekul pektin bertujuan untuk penggunaannya dalam beberapa industri. Pektin dengan berat molekul tinggi diaplikasikan untuk bahan tambahan makanan, obat-obatan, dan bahan perekat, sedangkan bobot molekul kecil umumnya memiliki fungsi antibakteri dan prebiotik. Pada penelitian ini diperoleh berat molekul pektin pada kulit buah kluwih yaitu sebesar 16.177,83 g/mol. Sedangkan berat molekul pektin dari kulit buah sukun hasil penelitian Hermanto $B$ (2016) adalah $7.387,512 \mathrm{~g} / \mathrm{mol}$. Hal ini tidak sesuai dengan syarat mutu yang ditetapkan oleh Sufy (2015) yang menyatakan berat molekul pektin yaitu berkisar antara 30.000 - $100.000 \mathrm{~g} / \mathrm{mol}$. Namun berat molekul yang diperoleh belum mencapai syarat minimum yang ditetapkan mungkin dipengaruhi oleh faktor pelarut, metode yang digunakan dan pengotor yang diperoleh pada komponen pektin yang diperoleh.

\section{h. Spektrum IR pektin}

Hasil pengukuran spektrum FTIR menunjukkan kelompok gugus fungsi dan memberikan informasi struktural pektin hasil ekstraksi dari bahan baku limbah kulit buah kluwih (Artocarpus Camansi Blanco). Daerah yang sering dianalisa dengan spektroskopi inframerah adalah dalam kisaran bilangan gelombang $4000-600 \mathrm{~cm}^{-}$ ${ }^{1}$. Identifikasi pengukuran fungsional pektin 
dilakukan dengan menggunakan spektrofotometer infra merah (FTIR), dengan rentang bilangan gelombang yang digunakan 4500-500 $\mathrm{cm}^{-1}$. Gugus fungsional utama pektin biasanya terletak pada area bilangan gelombang 1000-2000 $\mathrm{cm}^{-1}$ (Ismail et al, 2012). Ikatan karbonil teresterifikasi berada pada bilangan gelombang $1740-1760 \mathrm{~cm}^{-1}$ (Ismail et al, 2012).

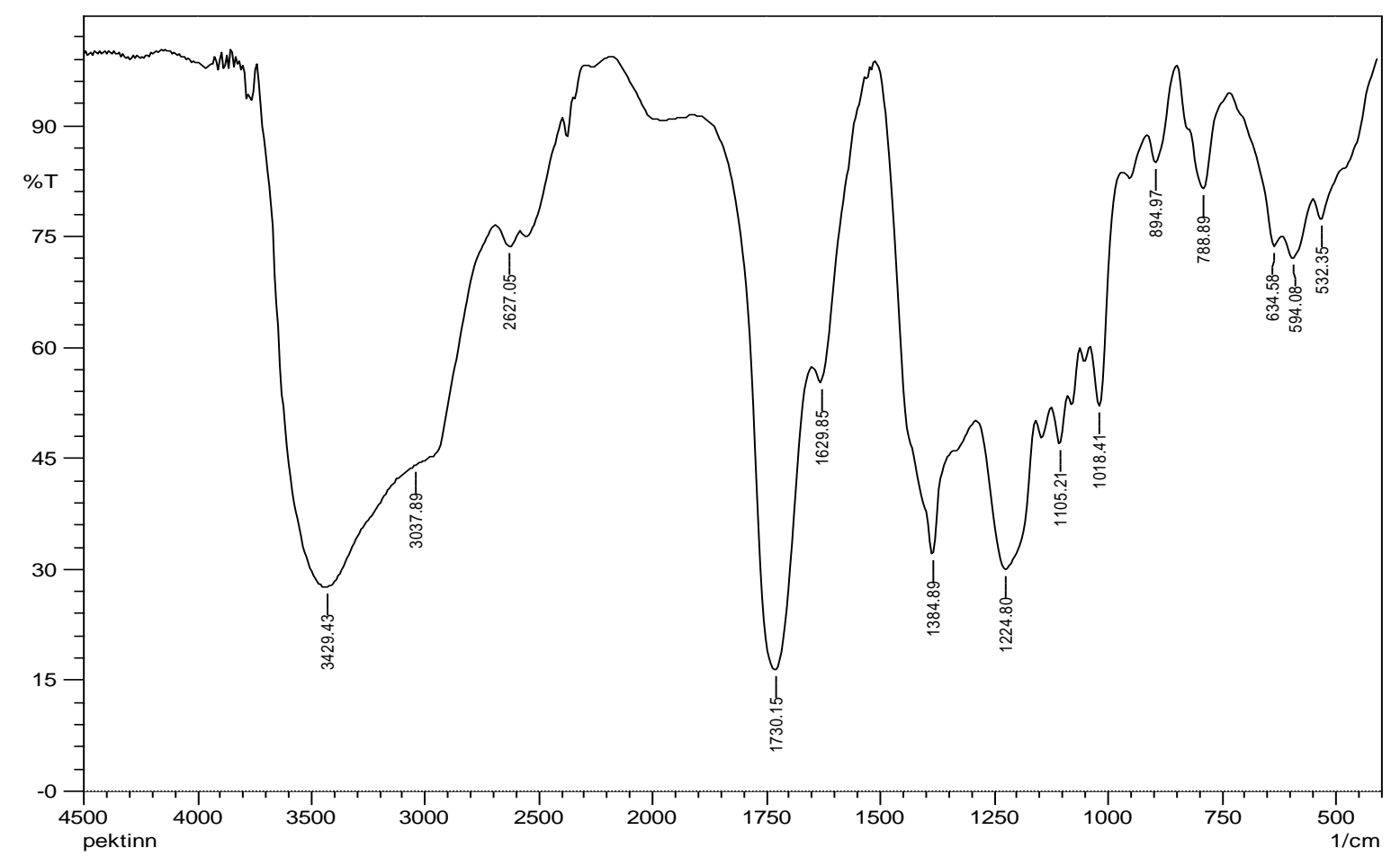

Gambar 3 Spektrum FTIR senyawa pektin kulit buah kluwih

Berdasarkan spektrum infra merah pektin, serapan dari gugus hidroksil $(-\mathrm{OH})$ terdapat pada bilangan gelombang $3429,43 \mathrm{~cm}^{-1}$ (Gambar 3). Pada penelitian yang telah dilakukan oleh Fitria (2013), gugus ulur $-\mathrm{OH}$ terletak pada bilangan gelombang $\quad 3420,14 \mathrm{~cm}^{-1}$, dan Penelitian yang dilakukan oleh (Madjaga et al., 2017), spektrum ulur -OH terletak pada bilangan gelombang $3412,08 \mathrm{~cm}^{-1}$. Hasil yang diperoleh diperkuat dengan pernyataan Hongping et al. (2004), yang menyatakan spektrum ulur $-\mathrm{OH}$ berada pada bilangan gelombang $3100-3700 \mathrm{~cm}^{-}$ 1. Sedangkan spektrum tekuk -OH terletak pada bilangan gelombang $1629,85 \mathrm{~cm}^{-1}$.
Hasil yang diperoleh diperkuat dengan pernyataan Hongping et al. (2004), yang menyatakan spektrum tekuk - $\mathrm{OH}$ berada pada bilangan gelombang $1600-1700 \mathrm{~cm}^{-}$ 1. Serapan pada bilangan gelombang 2900-3037,89 $\mathrm{cm}^{-1}$ menunjukan vibrasi ulur gugus $\mathrm{C}-\mathrm{H}$ alkana $\left(\mathrm{CH}_{3}\right)$. Pada penelitian yang telah dilakukan oleh Fitria (2013), gugus $\mathrm{C}-\mathrm{H}$ alkana $\left(\mathrm{CH}_{3}\right)$ terletak pada bilangan gelombang 2931,27 $\mathrm{cm}^{-1}$, dan Penelitian yang dilakukan oleh Madjaga et al. (2017), gugus C-H alkana $\left(\mathrm{CH}_{3}\right)$ terletak pada bilangan gelombang 2927,94 $\mathrm{cm}^{-1}$. Perbedaan hasil yang diperoleh disebabkan karena adanya pergeseran bilangan gelombang yang 
lebih tinggi akibat pengaruh dari jenis reaktan yang digunakan. Menurut Hadri et al (2012), yang menyatakan spektrum gugus $\mathrm{C}-\mathrm{H}$ alkan $\left(\mathrm{CH}_{3}\right)$ berada pada bilangan gelombang 2700-3050 cm Penyerapan pada bilangan gelombang $1730,15 \mathrm{~cm}^{-1}$ menunjukan adanya gugus $\mathrm{C}=\mathrm{O}$ (karbonil). Menurut penelitian Vita (2013), gugus karbonil $(\mathrm{C}=\mathrm{O})$ terletak pada bilangan gelombang $169,02 \mathrm{~cm}^{-1}$ dan penelitian yang telah dilakukan oleh Budi (2016), gugus karbonil $(\mathrm{C}=\mathrm{O})$ terletak pada bilangan gelombang $1724,36 \mathrm{~cm}^{-1}$. Menurut Pavia et al (2009), bilangan gelombang gugus karbonil terletak pada kisaran bilangan gelombang $1630-1850$ $\mathrm{cm}^{-1}$.

Pita serapan pada bilangan gelombang 1384,89 $\mathrm{cm}^{-1}$ menunjukkan adanya ikatan - C-H. Hal ini sesuai dengan penelitian Sufy (2015), menyatakan bahwa ikatan

$\mathrm{H}$ terletak pada bilangan gelombang $1421,60 \mathrm{~cm}^{-1}$. Menurut Pavia et al (2009), bilangan gelombang ikatan - C-H terletak pada kisaran bilangan gelombang 1450 $1375 \mathrm{~cm}^{-1}$.

Pita serapan pada bilangan gelombang $1105.21 \mathrm{~cm}^{-1}$, menunjukan ikatan dari eter (R-O-R) dari molekul pektin. Data didukung dengan penelitian Fitria (2013), bahwa spektra gugus eter berada pada bilangan gelombang 1151,29 $\mathrm{cm}^{-1}$, pada penelitian Sufy (2015), gugus eter (R-O-R) berada pada panjang gelombang $1146,73 \mathrm{~cm}^{-1}$. Pavia et al (2009) menyatakan bahwa ikatan eter (R-
O-R) berada pada kisaran spektum 1050 $1260 \mathrm{~cm}^{-1}$. Dari hasil gugus fungsional yang terukur dari spektrum FTIR dengan masing-masing serapan pada daerah panjang gelombang tertentu menunjukan kesesuaian dengan struktur pektin. Hal ini ditandai dengan terdapatnya vibrasi $\mathrm{OH}$, ikatan - $\mathrm{CH}_{3}$ pada cabang metoksil $\left(\mathrm{COOCH}_{3}\right)$, ikatan - $\mathrm{C}-\mathrm{H}$, gugus karbonil $(-\mathrm{C}=\mathrm{O})$ dan gugus eter (-O-) Fitria (2013).

\section{KESIMPULAN}

Rasio perbandingan sampel terhadap pelarut asam sitrat $5 \%$ yang menghasilkan rendemen pektin tertinggi pektin tertinggi sebesar $47,2 \%$ adalah 1:50 b/v. Waktu ekstraksi terbaik yang menghasilkan rendemen pektin tertinggi pektin tertinggi sebesar $48,30 \%$ adalah 120 menit.

Karakteristik pektin yang diperoleh antara lain yaitu kadar air 1,55\%, kadar abu 2,2\%, berat ekivalen 609,99 mg, kadar metoksil 11,49\%, kadar galakturonat $42,47 \%$, derajat esterifikasi $47,65 \%$, dan berat molekul 16.177,83 $\mathrm{g} / \mathrm{mol}$. Spektrum FTIR antara pektin standar dan hasil ekstraksi menunjukkan adanya kemiripan.

\section{DAFTAR PUSTAKA}

Akhmalludin, K A. (2009). Pembuatan pektin dari kulit cokelat dengan cara ekstraksi. Skripsi. Semarang: Universitas Diponegoro.

Arviani. (2009). Studi perbandingan metode ekstraksi pektin dari kulit jeruk (Citrus Sp). Skripsi. Palu: 
Jurusan Kimia Fakultas MIPA Universitas Tadulako.

Budiyanto, A., Yulianingsih. (2008). Pengaruh suhu dan waktu ekstraksi terhadap karakter pektin dari ampas jeruk siam (Citrus nobilis L). Jurnal Pascapanen. 5 (2): 37-44.

Christiani, A. A. M., Widjanarko, S. B., Purwantiningrum, I. (2014). Pembuatan pektin berwarna dari ampas apel manalagi dengan penambahan filtrat mawar merah. Jurnal Pangan dan Agroindustri. 2( 4).

Constenla, D., Lozano, J.E. (2002). Effect of pomace drying on apple pectin. Lebbensmittel Wissenschaf Und Technology.

Cowd, M.A. (1991). Kimia polimer. Bandung: Penerbit ITB

Evi, Z.N., Yuli, N., Rusdiansjah. (2013). Pengaruh suhu dan waktu terhadap hasil ekstraksi pektin dari kulit buah nanas. Simposium Nasional RAPI XII. FT UMS : K 3943

Fitria, V. (2013). Karakterisasi pektin hasil ekstraksi dari limbah kulit pisang kepok (Musa balbisiana ABB). Skripsi. Jakarta: Program Studi Farmasi Fakultas Kedokteran dan IImu Kesehatan Universitas Islam Negeri Syarif Hidayatullah.

Fitriani, V. (2003). Ekstraksi dan karakterisasi pektin dari kulit jeruk lemon (Citrus medica var Lemon). Skripsi. Bogor: Fakultas Teknologi Pertanian IPB.

Goycoolea, F.M., Cardenas A. (2003). Pectins from Opuntia Sp.: A Short Review. J.PACD

Hadri, M. El., Achahbar., Khamkhami, J., El., Khelifa, B., Faivre, V., Truong Cong, T., Bougrioua, F., Bresson, S. (2012). Raman spectroscopy investigation of mono- and diacylpolyoxyethylene glycols. France: Laboratoire De Physique The Systemes Complexes, UPJV. Amiens.
Hanum, F., Kaban, I M D., Tarigan, M A. (2012). Ekstraksi pektin dari kulit buah pisang raja (Musa sapientum). Jurnal Teknik Kimia USU, 1(2): 1226.

Hongping, H., Ray, F. L., Jianxi, Z. (2004). Infrared study of HDTMA. Intercalated Montmorillaonite. Elsevier.

Injilaudin, S.A., Lutfi, M., Nugroho, A. W. (2015). Pengaruh suhu dan waktu pada proses ekstraksi pektin dari kulit buah nangka (Artocarpus heterophyllus). Jurnal Keteknikan Pertanian Tropis dan Biosistem. 3(3).

International Pectins Procedures Association. (2003). What is pectin. http://www.ippa.info/history of Pekti n.htm. Diakses 20 Januari 2016.

Ismail, N S M., Ramli, N., Hani, N M., Meon, Z. (2012). Ekstraction and characterization of pectin from dragon fruit (Hylocereus polyhizus) using various extraction condition. Journal Sains Malaysiana. 41(1): 4145.

Kertesz, Z.I. (1951). The Pection substances. New York: Interscience Pub. Inc.,

Madjaga, B.H., Nrhaeni, Ruslan. (2017). Optimalisasi ekstraksi pektin dari kulit buah sukun (Artocarpus Altilis). KOVALEN, 3(2): 158-162.

Ngadiwiyana. (1996). Polimerisasi eugenol dengan katalis asam sulfat pekat. Skripsi. Yogyakarta: FMIPA UGM.

Nurhikmat, A. (2003). Ekstraksi pektin dari apel lokal : optimasi $\mathrm{pH}$ dan waktu hidrolisis. Jurnal Widyariset. 4.

Nurviani, N., Bahri, S., \& Sumarni, N. K. (2014). Ekstraksi dan karakterisasi pektin kulit buah pepaya (Carica papaya I.) Varietas cibinong, jinggo dan semangka. Natural Science: Journal of Science and Technology, 3(3).

O'Neil, MA., Ishii, T., Albersheim, P., Darvill, AG. (2014). 
Rhamnogalacturonan II: structure and function of a borate cross-linked cell wall pectin polysaccharide. Annu. Rev. Plant Biol. 55: 109-139.

Pardede, A., Ratnawati, D., Martono, A. (2013). Ekstraksi dan karakterisasi pektin dari kulit kemiri (Alleuritesmollucana willd). Media Sains, 5(1): 1-6.

Pavia, D., Lampman, G.M., Kriz, G.S., Vyvyan J.R. (2009). Introduction to spectroscopy edition IV. Washington: Departement of Chemistry. Western Wasington University.

Prasetyowati, Sari, K. P., Pesantri, H. (2009). Ekstraksi pektin dari kulit mangga. Jurnal Teknik Kimia , 16(4) : 42-49.

Putra, I. N. K. (2010). Optimasi proses ekstraksi pektin dami buah nangka (Artocarpus heterphyllus Lamk). J.Agritech. 30(3):158-163.

Ranganna, S. (2000). Handbook of analysis and quality controlfor fruit and vegetable products second edition. New Delhi: Tata McGrawHill Publishing Company Limited.

Silvana, P. (2013). Penggunaan berbagai jenis asam dalam ekstraksi pektin kulit buah kakao dari beberapa varietas buah kakao (Theobroma cacao, L). Skripsi. Palu: Jurusan
Kimia Fakultas MIPA Universitas Tadulako.

Susilowati, Siswanto, M., Luluk, E., Tutuk, H. (2013). Ekstraksi pektin dari kulit buah coklat dengan pelarut asam sitrat. Jurnal Teknik Kimia Teknologi Industri. 11(1).

Sufy, Q. (2015). Pengaruh variasi perlakuan bahan baku dan konsentarsi asam terhadap ekstraksi dan karakteristik pektin dari limbah kulit pisang kepok kuning (Musa balbisiana BBB). Skripsi. Jakarta: Program Studi Farmasi Fakultas Kedokteran dan IImu Kesehatan, UIN Syarif Hidayatullah.

Tuhuloula, A., Budiyarti, L., Fitriana, E N. (2013). Karakterisasi pektin dengan memanfaatkan limbah kulit pisang menggunakan Metode Ekstraksi. Jurnal Konversi, 2(1).

Utami, R. (2014). Ekstrasi pektin dari kulit kakao dengan pelarut ammonium oksalat. Skripsi. Banda Aceh: Fakultas Pertanian Universitas Syiah Kuaka, Banda Aceh.

Willats, W. G., Knox, J. P., \& Mikkelsen, J. D. (2006). Pectin: new insights into an old polymer are starting to gel. Trends in Food Science \& Technology, 17(3): 97-104. 